\title{
HISTOLOGICAL EFFECTS OF TITANIUM DIOXIDE NANOPARTICLES SIZE 10 NM IN MICE TESTES
}

\author{
Imad Taher Abdulla
}

Dept. of Biology, Faculty of Science, University of Zakho, Zakho, Kurdistan Region, Iraq - imad.abdulla@uoz.edu.krd

\begin{abstract}
:
In the present study, the histological effect of titanium dioxide nanoparticles (TDN) on testicular tissue of mature Mus musculus mice was investigated. The animals were divided into six groups, control group treated with TDN free saline and five groups treated with TDN as follow 5, 10, 50, 100 and $150 \mathrm{mg} / \mathrm{kg} \mathrm{B.W}$. The results showed that TDN has histological effects on testicular tissue like sever congestion, mild edema between seminiferous tubules (STs) and decrease the thickness of germinal epithelium at low concentrations, While, the histological changes at high concentrations involved disturbance in STs diameters, sever edema between STs, sever vaculation in the germinal epithelium and necrosis in spermatogonia, germinal epithelium and Sertoli cells.
\end{abstract}

KEYWORDS: Mus Musculus Mice, TDN, Histological, Seminiferous Tubules, Sertoli Cells.

\section{INTRODUCTION}

Titanium (Ti) is found in normal animals' tissues, but only in trace amounts (Schkroeder et al., 1963). But there is no proof of Ti being an vital element for human or animals (Dankovic et al., 2007). Titanium dioxide ( $\mathrm{Tio}_{2}$ ) amid most oxidation forms used worldwide in consuming and usage ways (Hongbo et al., 2013). Many researches pointed to that Tio 2 nanoparticals (NPs) were more cytotoxic to Leydig cells than diesel exhaust and carbon black NPs, and impacted gene expression, proliferation and viability of these cells (Komatsu et al., 2008). In nanomedicine, intraveneous and subcutaneous injection is a unique way to deliver $\mathrm{Tio}_{2} \mathrm{NPs}$ into human body (Zhao and Castranova, 2011). Many researches have revealed that Tioz fine particles (FPs) and NPs prompt genotoxicity and cytotoxicity in various cultured cell lines in animal model (Coskun et al., 2004). So our research aims to reveal the cytotoxic effect of Tioz on adult mice testes.

\section{MATERIALS AND MEHODS}

\subsection{Titanium dioxide}

Titanium Oxide Anatase nanopowder, APS: $10 \mathrm{~nm}$ was requested form M K Impex Corp. 6382 Lisgar Drive Mississauga, Ontario L5N 6X1 Canada, (mknano, www.mknano.com).

\subsection{Experimental animals}

Forty two albino male mice (four months old) with average weight $(25 \mathrm{gm})$ of strain Balb/c were used in this study. These animals were housed in plastic cages under standard laboratory conditions, including temperature at $22 \pm 2 \mathrm{C}^{\circ}$ and 12 hours light and 12 hours dark cycle. They were given standard diet as pellet and water ad libitum.

\subsection{Experimental design}

This experiment was designed to study effect of 5, 10, 50100 and $150 \mathrm{mg} / \mathrm{kg}$ body weight (BW) $\mathrm{Tio}_{2}$ on histological feature of male albino mice testes. The animals of this study were randomly divided into six groups $(n=7)$ for each group, as follow: first group is (control group), the males of this group were treated with TDN free normal saline $(0.9 \%)$. While other five groups were intraperitoneal (IP) injected with 5, 10, 50100 and $150 \mathrm{mg} / \mathrm{kg}$ BW Tio2 respectively. Tio2 was administered daily for fourteen days. At the end of the experiment all animals were subjected to postmortem dissection to obtain the testes (Liu et al., 2009).

\subsection{Histologic examination}

All animals were subjected to anesthetizing with $0.2 \mathrm{ml}$ ketamine/zylazine (1:1 volume/volume). Then the testes were removed and fixed in bouine solution for 8-24 hours. After fixation the fixed testes were embedded in paraffin wax, sectioned at $5 \mu \mathrm{m}$ using rotary microtome (microTec Laborgerate $\mathrm{GmbH}$ Rudolf-Diesel-Straße, Walldorf, Germany) and stained with hematoxylin and eosin ( $\mathrm{H}$ and $\mathrm{E})$. Then the general feature of the testicular sections were examined under light microscope (Culling et al., 1985).

\section{RESULTS}

Figure 1 showed the testicular cross section of control group. This testis was surrounded by a thick capsule of dense connective tissue, the tunica albuginea and within the testis the well development of seminiferous tubules (STs) were observed. In addition to active spermatogenesis was observed in nearly all the tubules. In the testicular cross sections of $5 \mathrm{mg} \mathrm{Tio} 2 \mathrm{NP} / \mathrm{kg} \mathrm{BW}$ (Figures 2, 3), the spermatogenesis process was increased compared to the control group (Figure 1). Whereas treatment with $10 \mathrm{mg} / \mathrm{kg}$ BW Tio2 NPs caused shrinkage of STs which associated with edema and hypoplasia of germinal epithelium (Figures 4, 5). Germinal epitelium hyperplasia, sever edema and obvious decreased in spermatogenesis cells were observed and recorded in group of $50 \mathrm{mg} / \mathrm{kg} \mathrm{BW} \mathrm{Tio}_{2} \mathrm{NPs}$ in comparison with both lower concentrations and control (Figures 6, 7). But treatment with 100 and $150 \mathrm{mg} / \mathrm{kg} \mathrm{BW} \mathrm{Tio} 2$ NPs resulted in acute necrosis and pronounced cytoplasmic vaculation of germ cells towards the periphery of STs. In addition to the destruction of these tubules and severe loss of germ cells (8-12). 


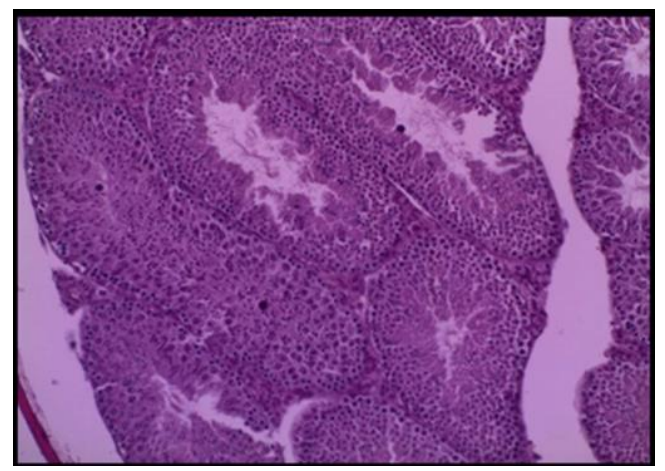

Figure 1. Histological section of control mice testes showing normal structure of seminiferous tubule (H\&E x 100).

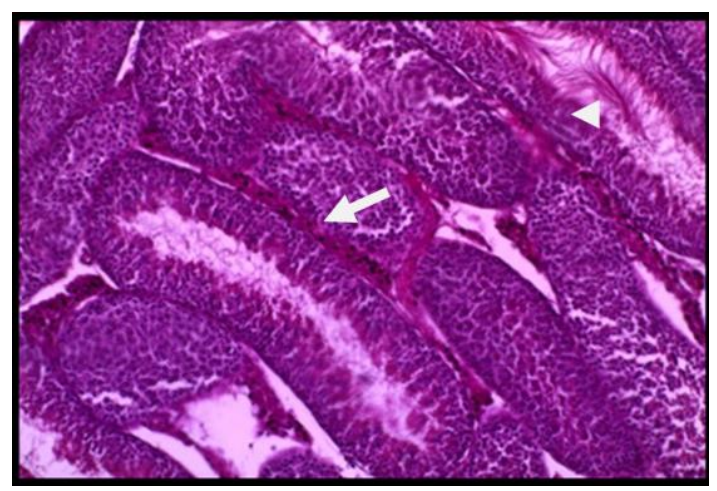

Figure 2. Histological section of mice testes treated with $\mathrm{TiO} 25$ $\mathrm{mg} / \mathrm{kg}$ body weight for 14 days showing sever congestion of blood vessel (arrow) and increases of spermatogenesis (head arrow) (H\&Ex100)

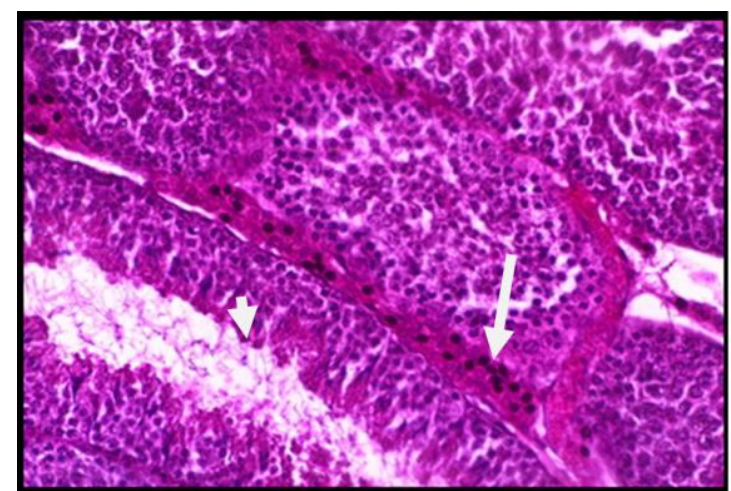

Figure 3. Histological section of mice treated with $\mathrm{TiO} 25 \mathrm{mg} / \mathrm{kg}$ body weight for 14 days showing sever congestion of blood vessel (arrow) and increases in spermatogenesis (head arrow) (H\&E x200).

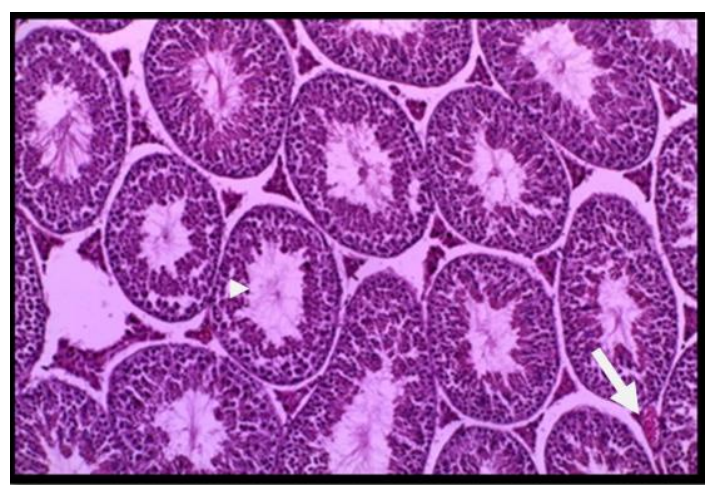

Figure 4. Histological section of mice testes treated with $\mathrm{TiO} 210$ $\mathrm{mg} / \mathrm{kg}$ body weight for 14 days showing decrease in spermatogenesis (head arrow) sever congestion of blood vessel (arrow) and edema between STs $(\mathrm{H} \& \mathrm{E}$ x100).

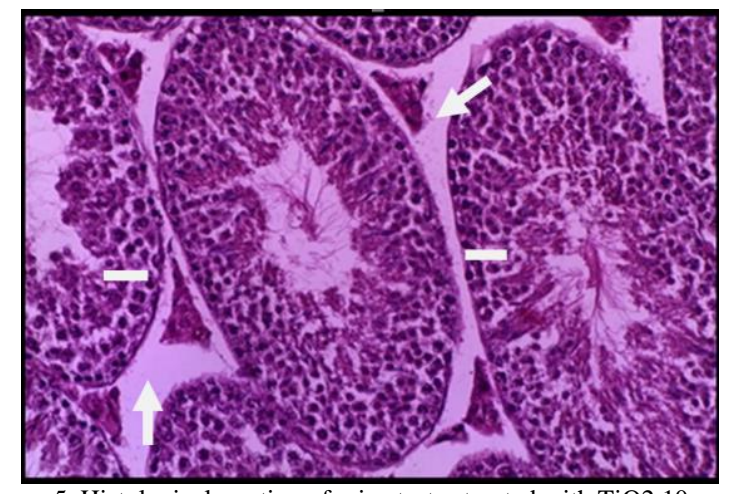

Figure 5. Histological section of mice testes treated with TiO2 $10 \mathrm{mg} / \mathrm{kg}$ body weight for 14 days showing decrease thickness of germinal epithelium (line) with sever congestion of blood vessel and edema between STs (arrow) (H\&E x200).

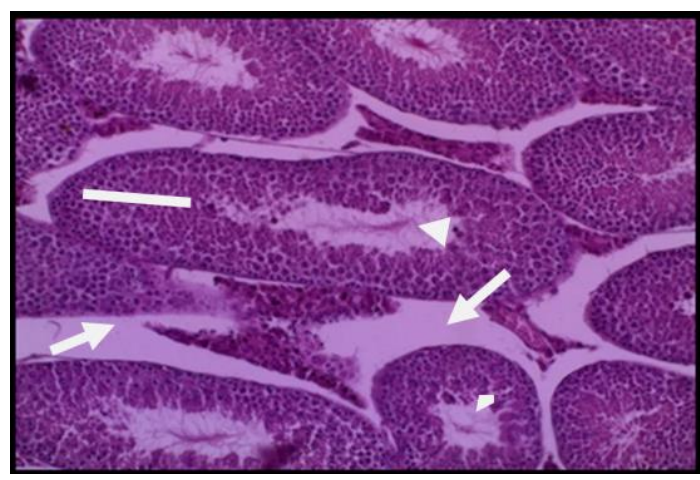

Figure 6: Histological of section of mice testes treated with $\mathrm{TiO} 250$ $\mathrm{mg} / \mathrm{kg}$ body weight for 14 days showing hyperplasia in germinal epithelium (line), sever edema between STs (arrow) and decreases of spermatogenesis (head arrow) (H\&E x100).

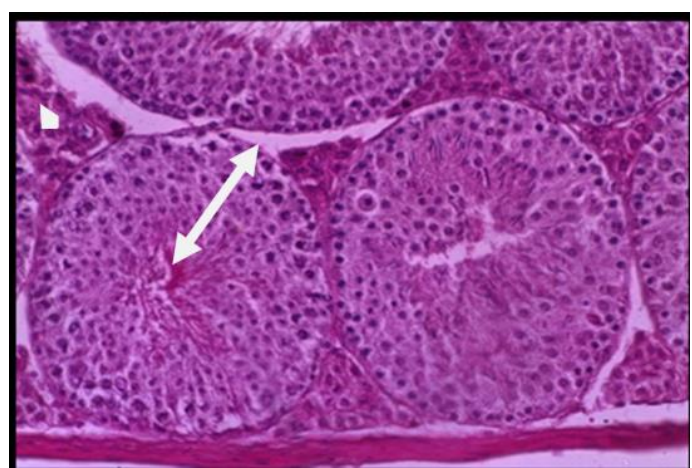

Figure 7. Histological of section of mice testes treated with $\mathrm{TiO} 250$ $\mathrm{mg} / \mathrm{kg}$ body weight for 14 days showing hyperplasia in germinal epithelium, sever edema between STs, decreases of spermatogenesis (double head arrow) and sever congestion of blood vessel (head arrow) (H\&E x200)

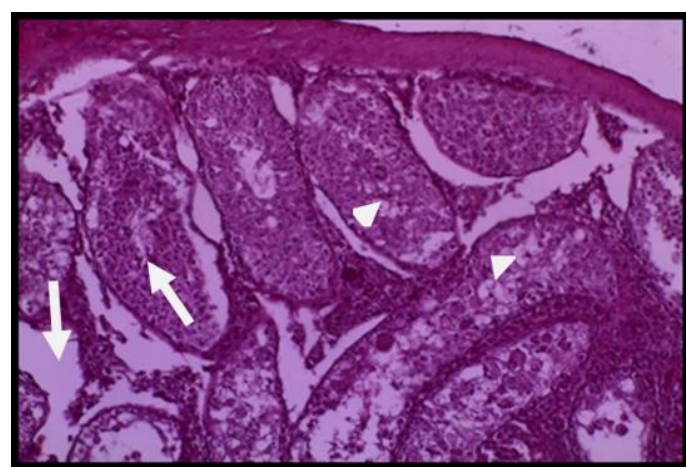

Figure 8. Histological section of mice testes treated with TiO2 NP 100 $\mathrm{mg} / \mathrm{kg}$ body weight for 14 days showing sever vacuolation and necrosis in germinal epithelium (head arrow), sever edema amid STs and no spermatogenesis with cellular debris in the lumen of STs (arrow) (H\&E $\mathrm{x} 100$ ). 


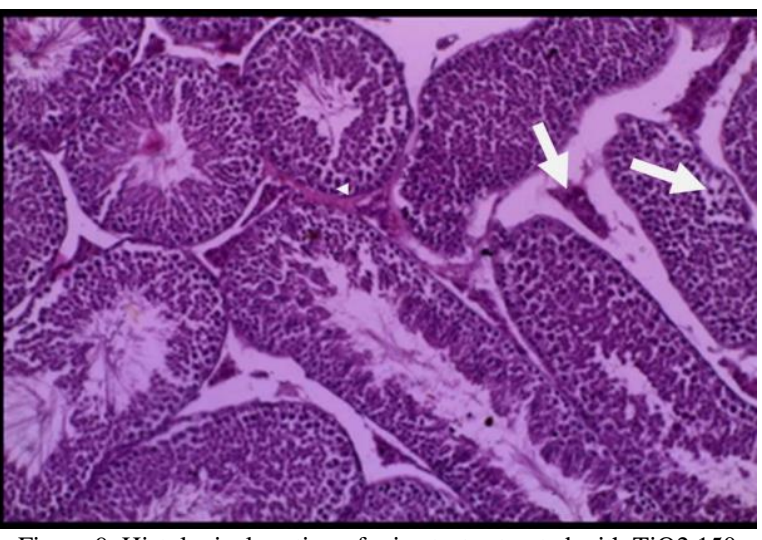

Figure 9. Histological section of mice testes treated with $\mathrm{TiO} 2150$ $\mathrm{mg} / \mathrm{kg}$ body weight for 14 days showing sever necrosis in germinal epithelium and interstitial cells (arrow) and sever congestion of blood vessel (head arrow) (H\&E x100).

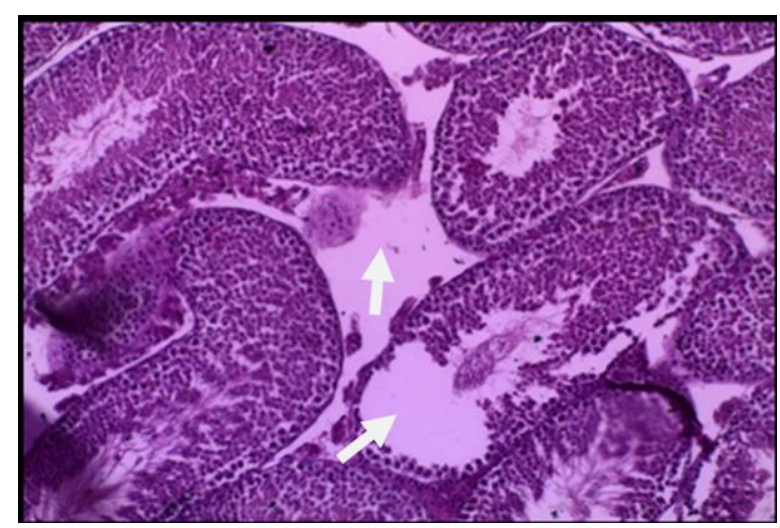

Figure 10: Histological section of mice testes treated with $\mathrm{TiO} 2150$ $\mathrm{mg} / \mathrm{kg}$ body weight for 14 days showing sever necrosis in germinal epithelium and interstitial cells and sever edema amid STs (arrow) (H\&E x 100).

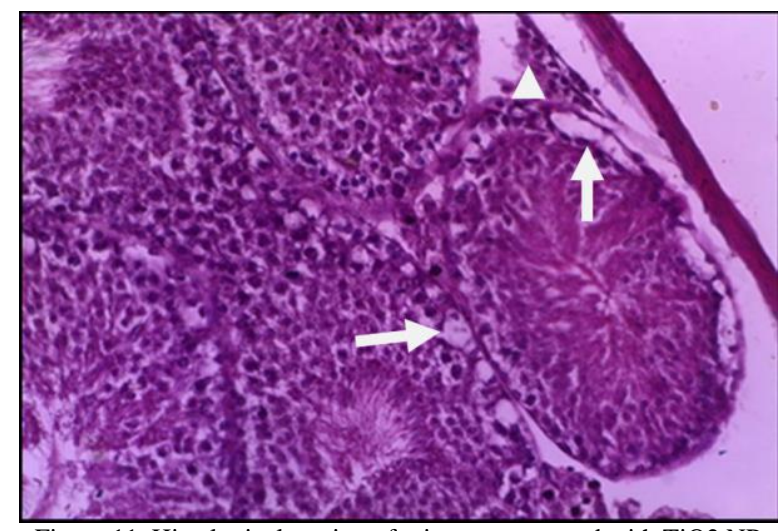

Figure 11. Histological section of mice testes treated with TiO2 NP

$150 \mathrm{mg} / \mathrm{kg}$ body weight for 14 days showing sever necrosis of germinal epithelium (arrow) and interstitial cells (head arrow) (H\&E $\mathrm{x} 100)$.

\section{DISCUSSION}

Titanium dioxide nanoparticles are vastly used like rubber, plastics, ceramics, paints, (Ashraf et al., 2009) and as drug constituents, food colorant vehicle, (Medina et al., 2007; Jiang et al., 2008) and in water purification (Fujishima et al., 2008; Wang et al., 2008; Trouiller et al., 2009). Although, intravenous and subcutaneous injection of TDN is unique way to deliver TDN into human body, however, the transplanted graft Nano-medicine application showing another way to deliver TDN to the human body (Zhao and
Castranova, 2011). So, in the present study TDN size $10 \mathrm{~nm}$ was delivered intraperitoneally to Mus musculus mice.

The observations of the current results showed the appearance of symptoms of acute toxicity with increasable doses, which reveals passive behavior, loss of appetite, tremor, and lethargy, that is confirmed with Ma et al., (2010) by using $50 \mathrm{~nm}$ TDN (Wang et al., 2007).

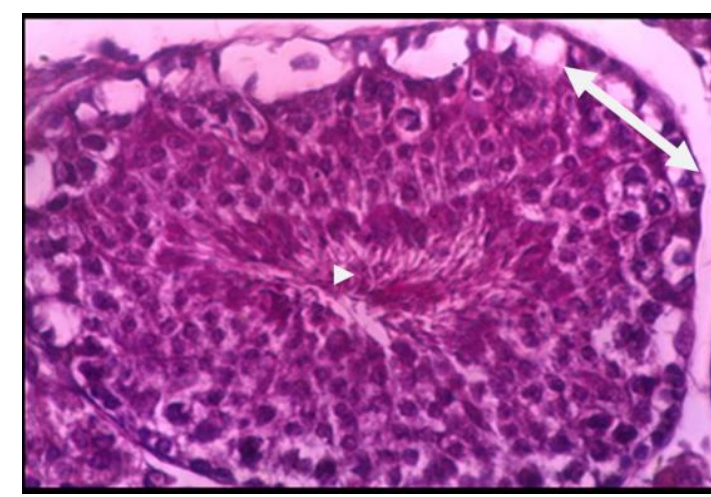

Figure 12. Histological of section of mice testes treated with $\mathrm{TiO} 2 \mathrm{NP}$ $150 \mathrm{mg} / \mathrm{kg}$ body weight for 14 days showing sever necrosis of spermatogonia, vacuolation and edema of STs (double head arrow) and no spermatogenesis (head arrow) (H\&E x200).

On the contrary of our results, Mahrous (Mahrousa, 2004) recorded that oral treatment of male rats with $4 \mathrm{mg} / \mathrm{kg} \mathrm{B.W}$ of TDN for 90 days results a significant decrease in their body weight. Wang et al, (2007) are found that using acute oral administration of TDN $5 \mathrm{mg} / \mathrm{kg} \mathrm{B}$.W decrease body weight of all treated mice, this may return to the way of TDN delivered to body, where IP route affect on signaling process (testes) whereas the oral route affect metabolic processes.

Ahotupa and Huhtaniemi, (1992) showed that TDN induced spermatogenic injury may be cause to formation of free radicals in the testicular tissue and spermatogenesis, this comes confirmed with the recent results.

It has been reported that TDN causes stress due to high level of nitric oxide in rat serum, (Herrero et al., 1997) which leads to decrease of cholesterol the precursor of testosterone, and finally disturbances of gonadotrophin releasing hormone (Ferrini et al., 2001) and decrease spermatogenesis and testicular inflammation, this is confirmed with recent results except $5 \mathrm{mg} / \mathrm{kg} \mathrm{B.W}$ that show increasing of spermatogenesis.

Many studies showed that TDN have the ability to penetrate the blood-testis barrier and induce toxic effects on male germ cells (Komatsu et al., 2008; Gao et al., 2013), and forming reactive oxygen species then it increases antioxidant enzyme activity (Afaq et al., 1998) like glutathione reductase, superoxide dismutase (Nabela et al., 2010) and same result reported as used ultrafine titanium dioxide that leads to testicular histologic damages, these findings come confirmed with recent results which show acute histologic damages in germ epithelium and testicular tissue in addition to significant decreasing in spermatogenesis.

\section{REFERENCES}

Afaq, F.; Abidi, P.; Matin, R. and Rahman, Q. (1998). Cytotoxic, prooxidant effects and antioxidant depletion in rat lung alveolar macrophages exposed to ultrafine titanium dioxide. J. of Appl. Toxicol. 18 (5): 307-312.

Ahotupa M, and Huhtaniemi I. (1992). Impaired detoxification of reactive oxygen and consequent oxidative stress in experimentally criptorchid rat testis. Biol. Reprod., 46: 11141118 .

Ashraf MM, Marwa IA, and Peter AN (2015) Reproductive toxicity investigation of titanium dioxide nanoparticles in male albino rats. W.J. Pharm. and Pharmaceut. Sci. 10 (4): 34-49. 
Coskun O, Ocakci A, Bayraktaroglu T, and Kanter M (2004). Exercise training prevents and protects streptozotocininduced oxidative stress and beta-cell damage in rat pancreas. Tohoku J. Exp. Med. 203. 145-154.

Culling C.F.A.; Allison R.J. and Barr W.T. (1985). Cellular pathology technique. Butterworth and Co. (Publishers) 1 st ed., London.

Dankovic D, Kuempel E, and Wheeler M (2007) An approach to risk assessment for TiO2. Inhal Toxicol, 19(Suppl 1):205212

Ferrini M, Wang C, Swerdloff R, SinhaHikim A, Rajfer J, and Gonzalez-Cadarid N. (2001). Aging related increased expression of inducible nitric oxide synthase and cytotoxicity markers in rat hypothalamic region associated with male reproductive function. Neuroendocrinology, 74 (1): 1-11.

Fujishima A, Zhang X, and Tryk DA. (2008). Ti photocatalysis and related surface phenomena. Surface Science Reports, 63: 515-582.

Gao G, Ze Y, Zhao X, Sang X, Zheng L, Ze X, Gui S, Sheng L, Sun Q, Hong J, Yu X, Wang L, Hong F, and Zhang X. (2013). Titanium dioxide nanoparticle-induced testicular damage, spermatogenesis suppression, and gene expression alterations in male mice. Journal of Hazardous Materials, 259:133-143.

Herrero MB, Viggiano JM, Martinez SP, and Gimeno MF, (1997). Evidence that nitric oxide synthase is progesteroneinduced acrosomal exocytosis in mouse spermatozoa. Repro, Fert. and Devel., 9:1 -10.

Hongbo S, Ruth M, Vincent C and Jinshun Z (2013) Titanium dioxide nanoparticles: a review of current toxicological data. Particle and Fibre Toxicology, 8977-10-15.

Jiang J, Oberdorster G, Elder E, Gelein R, Mercer P, and Biswas P. (2008). Does nanoparticle activity depend upon size and crystal phase? Neurotoxicology, 2: 33-42.

Komatsu T, Tabata M, Kubo-Irie M, Shimizu T, Suzuki K, Nihei Y, and Takeda K (2008) The effects of nanoparticles on mouse testis Leydig cells in vitro. Toxicol In Vitro, 22:18251831.

Liu H, Ma L, Zhao J, Liu J, Yan J, Ruan J, and Hong F (2009) Biochemical toxicity of nanoanatase $\mathrm{TiO} 2$ particles in mice. Biol Trace Elem Res, 129:170-180.

Ma L, Liu J, Li N, Wang J, Duan Y, Yan J, Liu H, Wang H, and Hong F (2010). Oxidative stress in the brain of mice caused by translocated nanoparticulate $\mathrm{TiO} 2$ delivered to the abdominal cavity. Biomaterials, 31:99-105.

Mahrousa MHK. (2004). Cytogenetic and biochemical effects of some food colors in rats. Ph. D. thesis submitted to Animal Production Department, Faculty of Agriculture, Cairo University.

Medina C, Santos-Martinez MJ, and Radomski A. (2007). Nanoparticles: Pharmacological andtoxicological significance. Br. J. Pharmacol., 150: 552-558.

Nabela I, EL- Sharkawy S, Hamza M, and Ehsan, HA, (2010). Toxic Impact of Titanium Dioxide (TiO) In Male Albino Rats with Special Reference to its Effect on Reproductive System. J Ameri.Sci. 6(11): 865-872.

Schkroeder HA, Balassa JJ, and Tipton IH (1963) Abnormal trace metals in man: titanium. J Chronic Dis, 16:55-69.

Trouiller B, Reliene R, Westbrook A, Solaimani P, and Schiestl RH. (2009). Titanium dioxide nanoparticles induce DNA damage and genetic instability in vivo in mice. Cancer Res. 69: 87848789 .

Wang J, Chen C, and Liu Y. (2008). Potential neurological lesion after nasal instillation of $\mathrm{TiO}$ nanoparticles in the anatase and rutile crystal phases. Toxicology Letters, (183): 72-80.

Wang J, Zhou G, Chen C, Yu H, Wang T, Ma Y, Jia G, Gao Y, Li B, Sun J, Li Y, Jiao F, Zhao Y, and Chai Z. (2007). Acute toxicity and biodistribution of different sized titanium dioxide particles in mice after oral administration. Toxicology Letters, 168: 176-185.

Zhao J, and Castranova V (2011) Toxicology of nanomaterials used in nanomedicine. J Toxicol Environ Health B Crit Rev, 14:593632 .

كارتيكرنا مادهي نانو دوانوكسيدى تيتانيوم لسهر شانيّن ئهندامي زاوزيّ (كَونى) مشكى سيى

كورتيا ليّكولينى

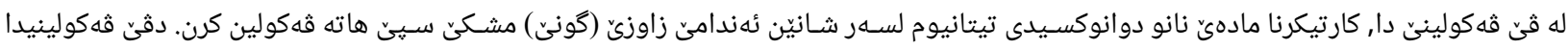

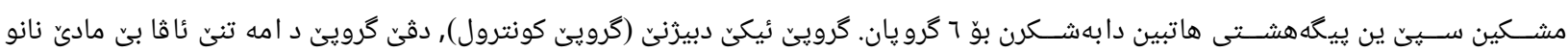

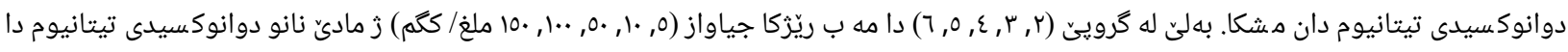

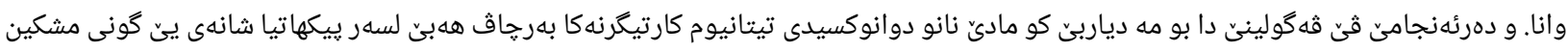

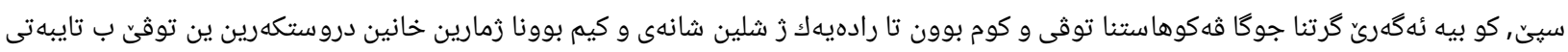

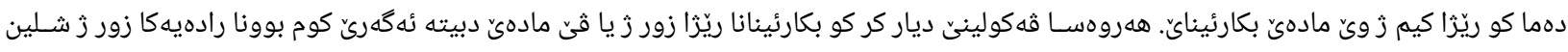

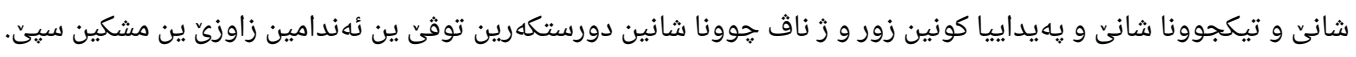

تاثير النسيجي لثاني اوكسيد التيتانيوم النانوية على الانسجة الخصوية للفئران

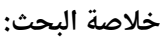

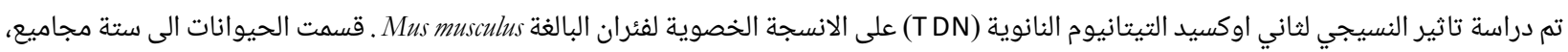

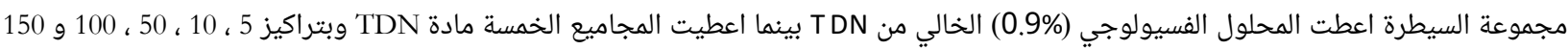

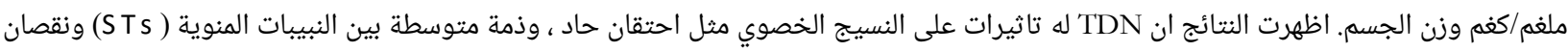

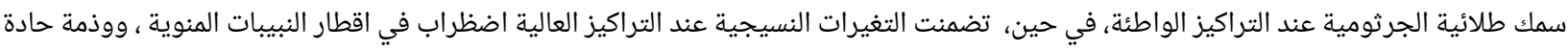

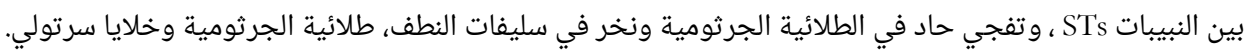

